\title{
Assessment and Trend of Land Cover Land Use Changes in Owerri and Environs, South Eastern Nigeria
}

\author{
Stanley I. Echebima ${ }^{1}$, Andrew A. Obafemi ${ }^{2}$, Benjamin C. Ndukwu ${ }^{3}$ \\ Institute of Natural Resources, Environment and Sustainable Development, University of Port Harcourt, Port Harcourt, Nigeria \\ Email: ^sechebima@yahoo.com,Andrew.obafemi@uniport.edu.ng,Benjamin.ndukwu@uniport.edu.ng
}

How to cite this paper: Echebima, S.I., Obafemi, A.A. and Ndukwu, B.C. (2019) Assessment and Trend of Land Cover Land Use Changes in Owerri and Environs, South Eastern Nigeria. Natural Resources, 10, 284-298.

https://doi.org/10.4236/nr.2019.107018

Received: June 7, 2019

Accepted: July 28, 2019

Published: July 31, 2019

Copyright $\odot 2019$ by author(s) and Scientific Research Publishing Inc. This work is licensed under the Creative Commons Attribution International License (CC BY 4.0).

http://creativecommons.org/licenses/by/4.0/

\section{c) (i) Open Access}

\begin{abstract}
This study examined land cover and land use changes (LCLUC) in Owerri and environs from 1986 to 2016 and went further to determine the trend in the change of each LCLUC class. The satellite imagery of the area over the three decades was characterized into the different LCLUC classes and the changes in the areal extent of the different LCLUC classes were calculated and plotted, followed with the estimation of the trend using linear regression analysis method. The result revealed that over the three decades, forests and sparse vegetation respectively decreased at a rate of $0.73 \%$ and $0.05 \%$ of the total land area per year while built up areas increased almost equally in the opposite direction at a rate of $0.65 \%$ of the total land area per year. Open spaces and water bodies decreased at the rate of $0.11 \%$ and $0.02 \%$ of the total land area respectively which were as a result of the pressure for resources like land and sand for built infrastructure. A model was derived for the LCLUC and it revealed that Owerri and environs may be devoid of vegetal cover in about 2 decades (2039) if the current rate of conversion of forests to built-up infrastructure is not abated. This whole LCLUC scenario if not controlled may trigger changes in the local climate of the area and urgent steps are therefore needed to create awareness to all the stakeholders in the area on the need for sustainable land and natural resources use, tree planting, urban spatial plan and controls in order to safeguard the environment, ecosystem and climate of the area for the future.
\end{abstract}

\section{Keywords}

Owerri, Imo State, Nigeria, Otamiri, Nworie, LCLUC, FAO, UNEP, IPCC

\section{Introduction}

Land use is the exploitation of natural resources by human in his immediate en- 
vironment and when this has taken place over a length of time causing an irretrievable transformation of the landscape, it is termed land use changes (LUC) or more generally land cover and land use changes (LCLUC). Land use is thus characterized by the arrangements, activities and inputs people undertake in a certain land cover type to produce, change or maintain it [1], and these arrangements, activities and inputs which include farming, housing, landscaping, amenities and infrastructure amongst others are as old as human evolution from the Neolithic time through the Holocene to the present day era. Other actions of human that change the landscape are deforestation, agriculture, urbanization, afforestation, reforestation, dumping of refuse and alterations to city planning, to mention a few. In Indonesia for instance, about $500 \mathrm{sq} \mathrm{km}$ of forest is cleared each year, much of which is replaced with oil palm plantation [2].

At a global scale and on a historical perspective, the model of the transition of land use from pristine natural ecosystem to modern day intensive agriculture and urbanization is shown in the figure (Figure 1). This has been defined to mean a transition from natural vegetation cover to frontier clearing, then to subsistence agriculture and small scale farming and finally to present day intensive commercial agriculture, urbanization, recreational parks, forest reserves, etc. [3].

Thus, agriculture and urbanization are major activities that lead to changes in land use, for the reason that an increase in population leads primarily to the demand for shelter and food and subsequently, amenities, industries and commercial housing. The model thus described is not universal, because it may not be simultaneously fit into all regions of the world, due to the peculiar circumstances like socio-political and economic situations which a region may be facing. The rate of transition for any nation or locality can be linear or non-linear depending on any of the circumstances just mentioned. For instance, some regions may be static on a particular transitional stage for too long, like infrastructure, due to

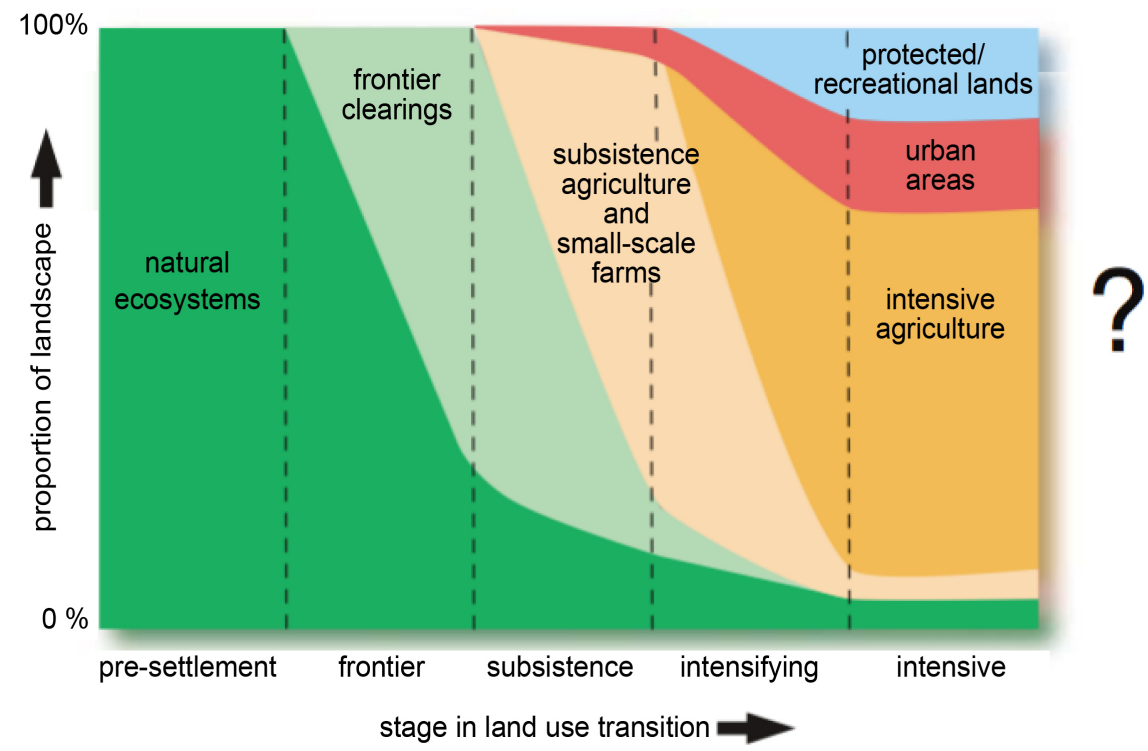

Figure 1. Land use transitions over time. Source: J. A. Foley, R. De Fries et al., 2005. 
economic strangulation or political instability as noticed in developing or underdeveloped nations, while other nations transit rapidly in all the facets like the western or developed economies.

Owerri town and its environs equally, have had a fair share of studies in transition of land-use over time (i.e. land use changes with time), which on average have demonstrated much vegetation cover in the 1980s and early 1990s transiting to modest increase in housing and agriculture in the late 1990s and early 2000 s and thereafter to massive urbanization that has continued to present day. Most of the activities leading to the LCLUC have been made to suit the local needs, which may either be justified or not. In their study of Owerri and environs, Nnaji et al. concluded that Built-up areas showed dramatic increase while other non-built-up surfaces substantially decreased over the decades from 1991 to 2014 [4]. In a parallel study of land use changes in Owerri municipal between 1994 and 2014, Okeke affirmed Nnaji's observations by stating that "the overall result (change detections) shows that built-up area and farmlands increased in size from 1994 to 2014, while other activities decreased" [5]. Chukwuocha and Blessing observed that built-up LUC class in 2006 and 2012 assumed a dramatic fast rate of change with farmland and vegetal cover been the most converted land use classes into built-up and riparian land and water bodies converted to major sand excavation sites [6]. These activities at that time could be as a result of increases in economic activities, infrastructural development or population growth (when projected from the 2006 population census data [7]).

With all these happenings, therefore, the study area can benefit from a probabilistic estimation of the transition of a particular LCLUC class into another, using tools like Markov Chain which Eludoyin et al. [8] have used to forecast the LCLUC transition in the nearby ObioAkpor LGA, Nigeria. Several scholars [9] [10] [11] have used it or its variants at other locations. Therefore forecasting the transition of vegetal covers into built up space is apt for Owerri and environs and other parts of the country experiencing the same rapid LCLUC transformations.

Apart from direct (or human-caused) changes to land cover, land use changes can also result indirectly from nature like volcanic eruptions, earthquakes, landslides, mudslides, flooding, drought and hurricanes amongst others, but these natural events have not occurred in Owerri and environs in recent or past memory.

Several studies have indicated that land-use change is a driver of climate change through changes in greenhouse gas, especially carbon dioxide $\left(\mathrm{CO}_{2}\right)$ emissions from the land and changes in energy and water balance at land surface [12]. The Intergovernmental Panel on Climate Change (IPCC) estimates that land use change (e.g. conversion of forest to agricultural land) contributes $1.6 \pm$ $0.8 \mathrm{Gt}$ carbon per year to the atmosphere [13]. Onyenechere, in his study revealed the increase in ambient air temperature in Calabar, Lagos and Kano [14]. In a recent study, Echebima et al. revealed that on average, the climate of Owerri and environs has changed and is warming up, though not at a uniform rate [15]. 
So, it will not be surprising if any adverse land use changes in Owerri and environ will be the cause for the change in the local climate. Owerri and Environs are the administrative capital of Imo State in south eastern Nigerian which was created in 1976 and at that time lacked most basic infrastructural befitting her new status, and then commenced rapid infrastructural developments thereby putting pressure on the available natural resources. Till date, these rapid infrastructural developments have gone unabated in order to meet ever changing and growing socio-economic needs which can be rightly or wrongly justified. These activities have no doubt led to LCLUC and have thus necessitated this study in order to understand the current state of things and proffer recommendations. Therefore, the study is concerned with land cover and land use changes (LCLUC) resulting from human activities in Owerri and environs from 1986 to 2016 and will further determine the rate of change (trend) of each LCLUC class which for consistency and comparison with previous studies and based on Anderson et al. [16], will use the following LCLUC classification namely Built-up area, Farmland or sparse vegetation, Open space, Forest or thick vegetation and Water body. The study will not only gave the empirical data on the changes of each LCLUC class in each decade studied, but will further adopt a novelty approach to use linear regression methods of line of best fit to determine the overall trend, pattern of LCLUC and behavior of natural resource use from which a projection/forecast can be made of the future size a particular LCLUC class.

\subsection{The Study Area}

The study area is Owerri urban and parts of its adjacent periurban towns delimited by the coordinates shown in the table (Table 1) and depicted in the figure (Figure 2). The area encompasses the entire Owerri municipal council and parts of the adjacent councils namely Owerri West LGA and Owerri North LGA. Two rivers namely, Otamiri flowing from the East and Nworie flowing from the west interspersed the study area and has a confluence at a point in Owerri town which then flows down south. The vegetation of the area is dominantly tropical rainforest with herbaceous plants forming the forest floor while trees form the canopies, but the density of the rainforest has drastically been reduced over the years due to human activities. Interspaced are light or sparse vegetation comprised mainly of shrubs and farm plants. The climate of the area is a tropical wet climate or monsoon climate according to the Koppen-Geiger weather classification [17], characterized by high temperature and humidity. It has both wet

Table 1. The corner coordinates of the study area (refer to Figure 4 for the corner points).

\begin{tabular}{ccc}
\hline Point & Longitude & Latitude \\
\hline E & $6^{\circ} 58^{\prime} 33.6^{\prime \prime} \mathrm{E}$ & $5^{\circ} 30^{\prime} 25.2^{\prime \prime} \mathrm{N}$ \\
F & $7^{\circ} 2^{\prime} 56.4^{\prime \prime} \mathrm{E}$ & $5^{\circ} 32^{\prime} 31.2^{\prime \prime} \mathrm{N}$ \\
G & $7^{\circ} 5^{\prime} 2.4^{\prime \prime} \mathrm{E}$ & $5^{\circ} 28^{\prime} 8.4^{\prime \prime} \mathrm{N}$ \\
$\mathrm{H}$ & $7^{\circ} 0^{\prime} 39.6^{\prime \prime} \mathrm{E}$ & $5^{\circ} 25^{\prime} 58.8^{\prime \prime} \mathrm{N}$ \\
\hline
\end{tabular}




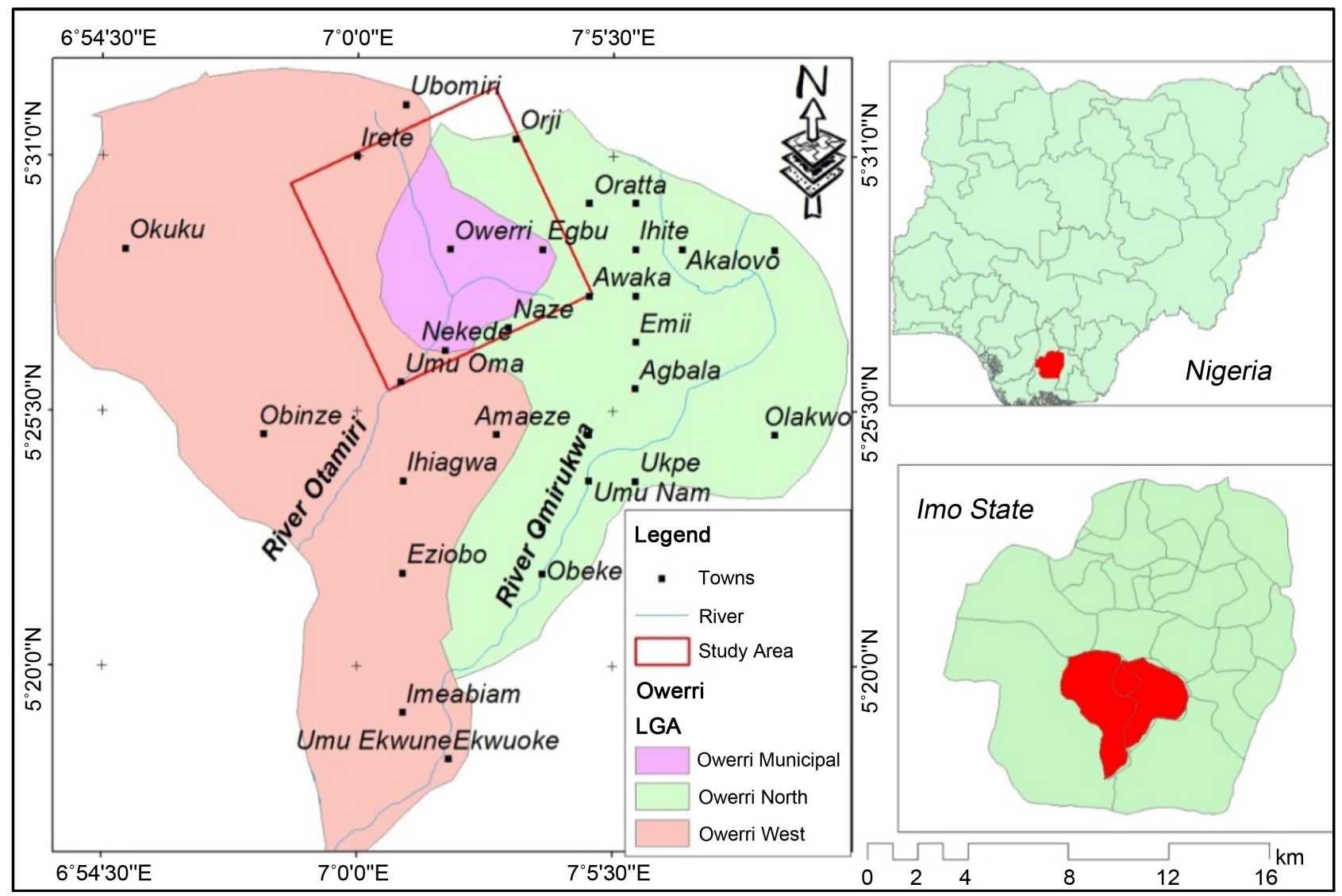

Figure 2. Map of Nigeria showing the location of the study area in Imo State. Source: Stanley I. Echebima, Andrew A. Obafemi and Benjamin C. Ndukwu.

season when rain falls between April and September and a dry season thereafter with drier dusty Harmattan period within it. The annual average temperature for is $26.4^{\circ} \mathrm{C}$ and average annual rainfall is $2219 \mathrm{~mm}$ [18].

\subsection{Materials and Methods}

Land Satellite (Landsat) imagery data and local maps for geo-reference were used. The Landsat Thematic mapper (TM) and Enhanced Thematic mapper (ETM) images of resolution $30 \mathrm{~m} \times 30 \mathrm{~m}$ for 1986, 2000 and 2016 that were used were obtained from the United States Geological Survey (USGS) through their Earth Explorer. The shapefiles used for generating the maps of the study area were acquired from the Nigerian National Space Research and Development Agency (NASRDA). The summary of the materials is given in the table (Table 2).

Geospatial technique using the Geographical Information Systems (GIS) and other related software platforms were used in the assessment of the changes in the LCLUC classes in the study area. The five main procedures adopted in this technique are summarized below namelyBand combination and image processing, Maximum Likelihood Classification, Statistical presentation of classified Land cover in hectares and accuracy assessment, Overlay analysis and 
Table 2. Data sources.

\begin{tabular}{ccccc}
\hline S/N & Type of Data & $\begin{array}{c}\text { Date of } \\
\text { Data }\end{array}$ & Scale of Data & Source \\
\hline 1. & Landsat 8 image & 2016 & $30 \mathrm{~m}^{\text {ETM+ }}$ & USGS \\
2. & Landsat 7 image & 2000 & $30 \mathrm{~m}^{\text {ETM+ }}$ & USGS \\
3. & Landsat 5 image & 1986 & $30 \mathrm{~m}^{\mathrm{TM}}$ & USGS \\
& Nigeria Shapefile Data. & 2013 & $\begin{array}{c}1: 15,140,906 \\
(\text { view scale })\end{array}$ & NASRDA \\
4. & & $1: 120,000$ & $\begin{array}{c}\text { GeoSat Environmental } \\
\text { Consults Owerri }\end{array}$ \\
\hline
\end{tabular}

Source: Stanley I. Echebima, Andrew A. Obafemi Benjamin C. Ndukwu and GeoSat Consult.

finally Change detection of LCLUC variability. The Supervised classification was done using a sampled training of the area. The final step of image classification is the accuracy assessment which shows quantitatively the level of accuracy of the pixels sampled during the training sample development.The classification scheme was based on the pre-established classification schemes used by previous researchers which referenced or modified Anderson, et al., UNEP/FAO [19], FAO [20] for land cover and land use class classifications. On this note therefore, this study adopted five classes based on the geography of the study area and in conformity with other scholars particularly Okeke, Nnaji, et al., Njoku, et al. [21] and Ukaegbu, et al., [22] which are: open spaces, forest (or thick vegetation), farmland (or sparse vegetation), built-up and water body. The land use maps of the years 1986, 2000 and 2016 were generated and the area in hectares (or square kilometers) of each LCLUC type in each year calculated in order to determine the change and percentage of change in the total area covered in the land use types. A plot of the areal changes and percentage changes is made using MS EXCEL and a line of best fit using linear regression method made in order to generate the trend line and the formula for the LCLUC pattern of the area.

\section{Results and Discussion}

The results of the work are presented starting with the LCLUC in the years 1986, 2000 and 2016 studied and thereafter followed with the trend analysis.

\subsection{Land Cover Land Use Changes in the Study Area}

The result of the LCLUC classification for 1986 is depicted in Figure 3 and summarized in Table 3. It revealed that the largest land cover was the forest, which a total of 3049.65 hectares making $37.41 \%$ of the entire study area. This was followed by Built up area which occupied a total of 2834.55 hectares which is about $34.77 \%$ of the entire study area. The third in that order was identified to be Farm/vegetation which was about 1979.28 hectares making up to $24.28 \%$. Water body and open space were the least of the land covers which occupied $2.26 \%$ and $1.28 \%$ respectively. 


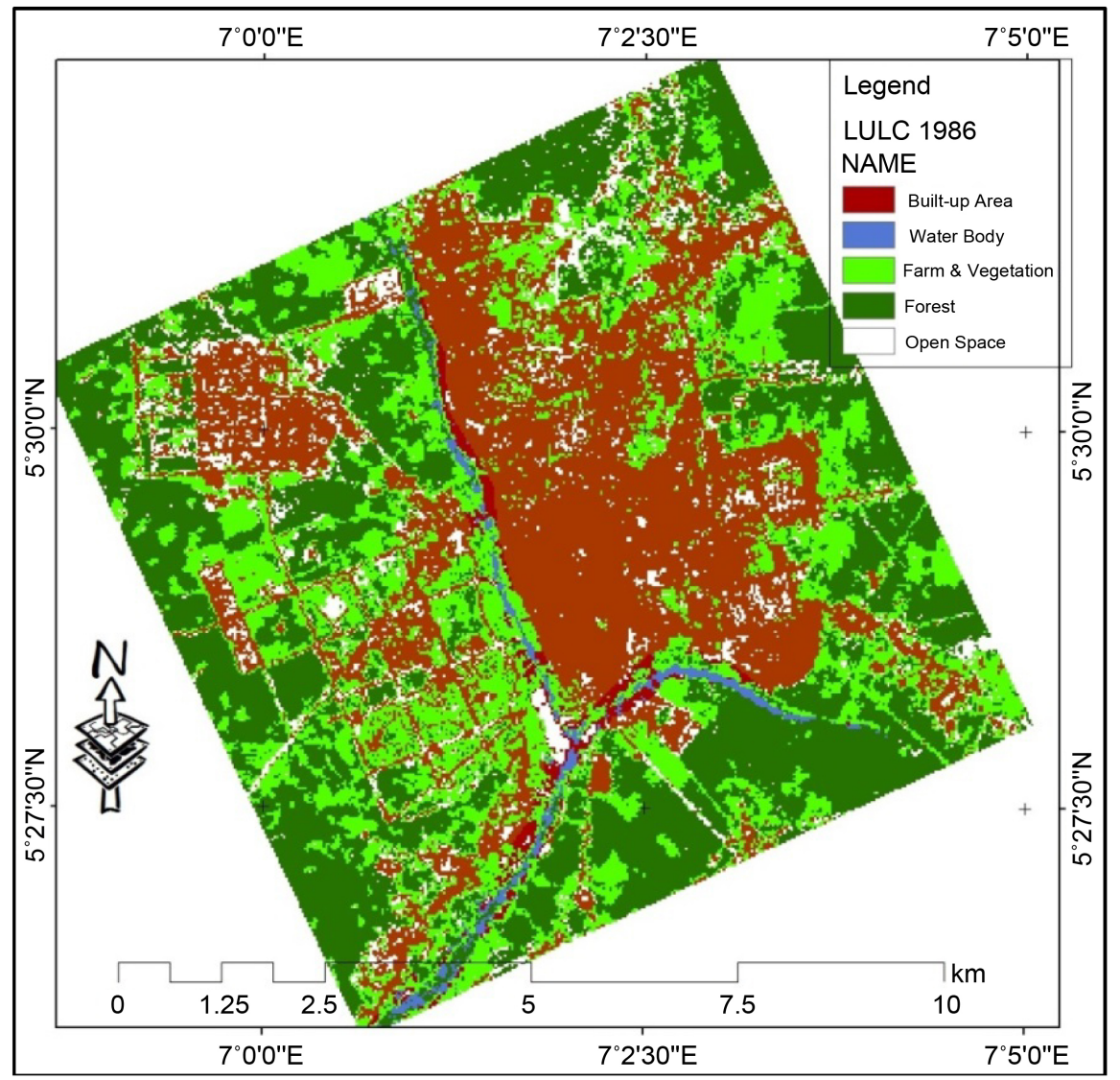

Figure 3. LCLUC of the study area in 1986. Source: Stanley I. Echebima, Andrew A. Obafemi and Benjamin C. Ndukwu.

Table 3. LCLUC distribution in 1986 and classification accuracy.

\begin{tabular}{ccccc}
\hline Name & Count & Area (Square Meter) & Area (Hectares) & \% LCLUC \\
\hline Built-up Area & 31,495 & $28,345,500$ & 2834.55 & 34.77 \\
Farm/Vegetation & 21,992 & $19,792,800$ & 1979.28 & 24.28 \\
Forest & 33,885 & $30,496,500$ & 3049.65 & 37.41 \\
Open Space & 2051 & $1,845,900$ & 184.59 & 2.26 \\
Water Body & 1160 & $1,044,000$ & 104 & 1.28 \\
Total & 90,583 & $81,524,700$ & 8152 & 100 \\
Accuracy Assessment & Overall Accuracy: $97.66 \%$ & Kappa Coefficient: 0.8291 \\
\hline
\end{tabular}

Source: Stanley I. Echebima, Andrew A. Obafemi and Benjamin C. Ndukwu.

\subsection{Land Cover Land Use Changes in the Study Area}

The spatial distribution for LCLUC classes in the year 2000 is shown in Table 4 and Figure 4. In that year, Built-up area occupied the largest space of 3111.12 hectares or $38.16 \%$ of the study area followed by forest which occupied a total of 2463.38 hectares which made up $31.44 \%$ of the study area. Farm/sparse vegetation maintained its third position with 2273.85 hectares making up $27.89 \%$ of the entire study area. Open space and water body occupied about 105.3 and 
Table 4. LCLUC distribution in 2000 and classification accuracy.

\begin{tabular}{ccccc}
\hline Name & Count & Area (Square Meter) & Area (Hectares) & \% LULC \\
\hline Built-up Area & 34,568 & $31,111,200$ & 3111.12 & 38.16 \\
Farm/Vegetation & 25,265 & $22,738,500$ & 2273.85 & 27.89 \\
Forest & 28,482 & $25,633,800$ & 2563.38 & 31.44 \\
Open Space & 1170 & $1,053,000$ & 105.3 & 1.29 \\
Water Body & 1098 & 988,200 & 98.82 & 1.21 \\
Total & 90,583 & $81,524,700$ & 8152.47 & $100 \%$ \\
Accuracy Assessment & Overall Accuracy: 82.91\% & Kappa Coefficient: 0.7072
\end{tabular}

Source: Stanley I. Echebima, Andrew A. Obafemi and Benjamin C. Ndukwu.

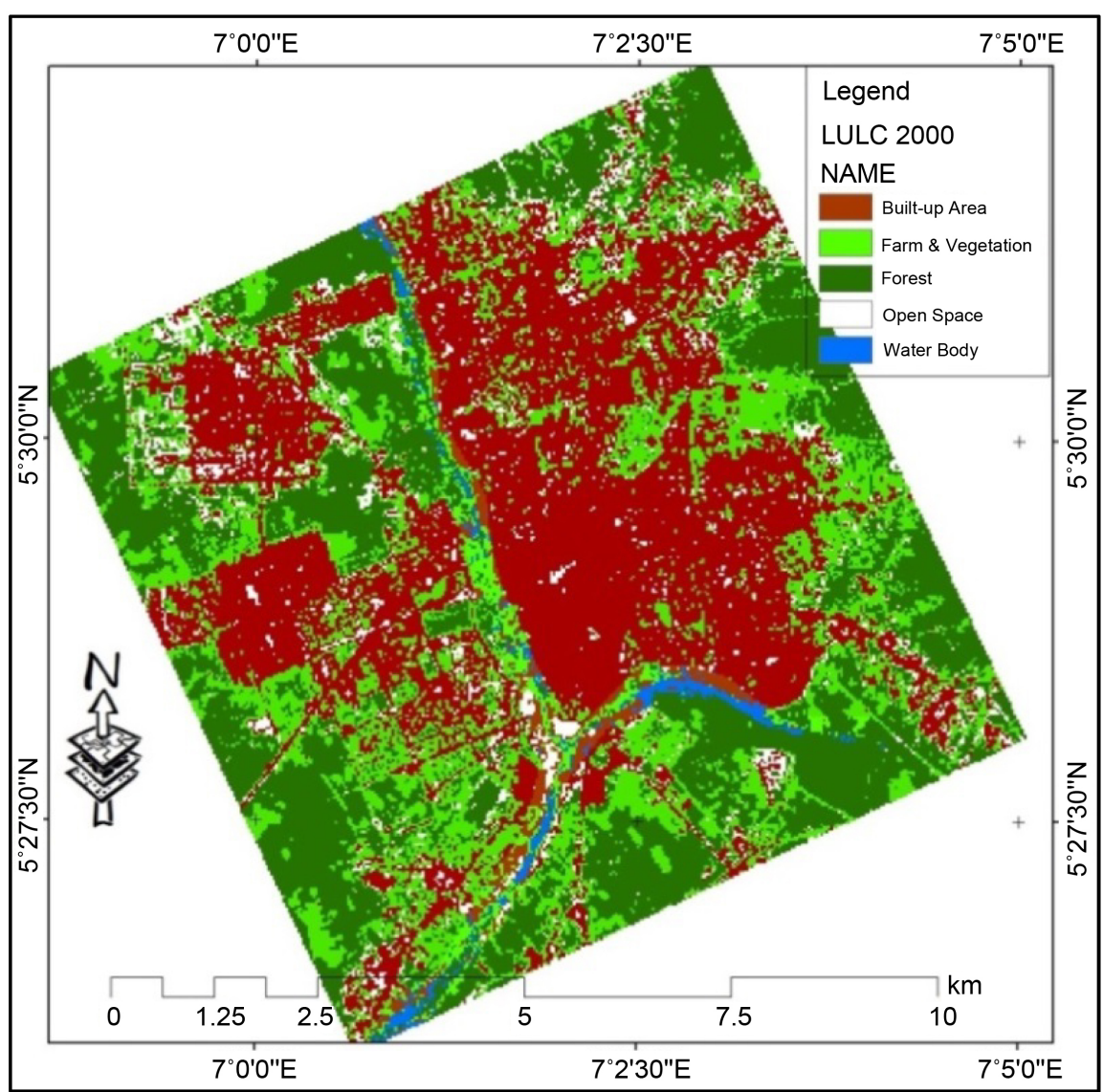

Figure 4. LCLUC of the study area in 2000. Source: Stanley I. Echebima, Andrew A. Obafemi and Benjamin C. Ndukwu.

98.82 hectares respectively tallying about $1.29 \%$ and $1.21 \%$ respectively of the entire study area.

\subsection{Land Cover Land Use Changes in the Study Area}

In 2016 as the results revealed in Table 5 and Figure 5, Built-up area became the dominant land cover, occupying a total of 4410.72 hectares making up about $54.10 \% \mathrm{t}$ of the entire study area, now followed by farm/sparse vegetation cover which made up 1881.9 hectares which is about $23.08 \%$ of the entire study area. 
Table 5. LCLUC distribution in 2016 and classification accuracy.

\begin{tabular}{ccccc}
\hline Name & Count & Area (Square Meter) & Area (Hectares) & \% LULC \\
\hline Built-up Area & 49,008 & $44,107,200$ & 4410.72 & 54.10 \\
Farm \& Vegetation & 20,910 & $18,819,000$ & 1881.9 & 23.08 \\
Forest & 14,184 & $12,765,600$ & 1276.56 & 15.66 \\
Open Space & 4815 & $4,333,500$ & 433.35 & 5.32 \\
Water Body & 1666 & $1,499,400$ & 149.94 & 1.84 \\
Total & 90,583 & $81,524,700$ & 8152 & 100 \\
Accuracy Assessment & Overall Accuracy: 83.87\% & Kappa Coefficient: 0.7323 \\
\hline
\end{tabular}

Source: Stanley I. Echebima, Andrew A. Obafemi and Benjamin C. Ndukwu.

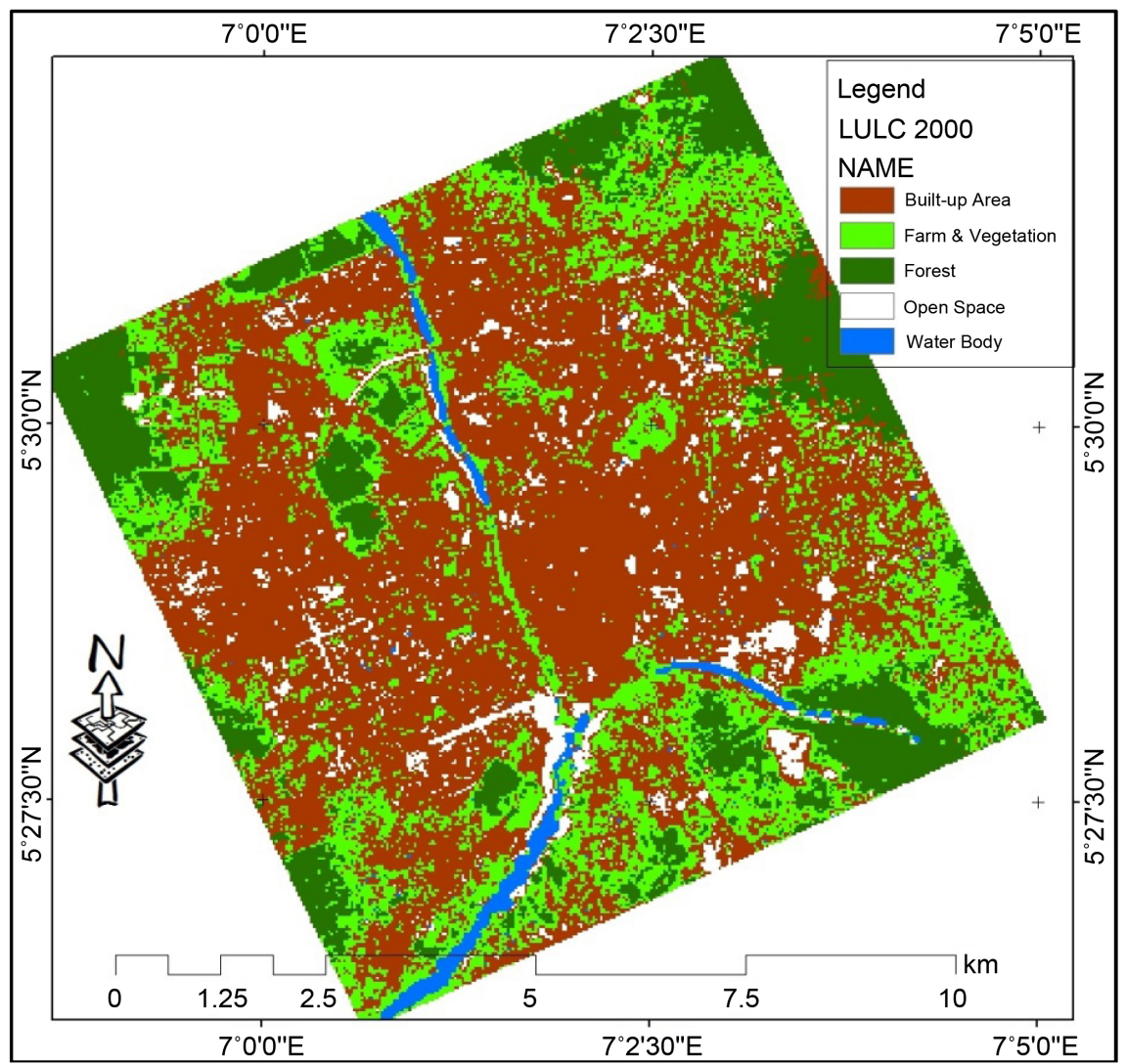

Figure 5. LCLUC of the study area in 2016. Source: Stanley I. Echebima, Andrew A. Obafemi and Benjamin C. Ndukwu.

Forest cover to a hit in the years leading up 2016 in been deforested and occupied a mere 1276.56 hectares making up to $15.66 \%$ of the entire study area. Open space was revealed to be 433.35 hectares making up to $5.32 \%$ while the water body is about 149.94 hectares which is equivalent to $1.84 \%$ of the entire study area.

\subsection{Change Detection Analysis}

The change detection analysis which was created by superimposing layer by layer, the land use forms from the years 1986, 2000 and 2016 is shown in Figure 6. Thus Built up cover was the dominant and significant land cover land use changes in 


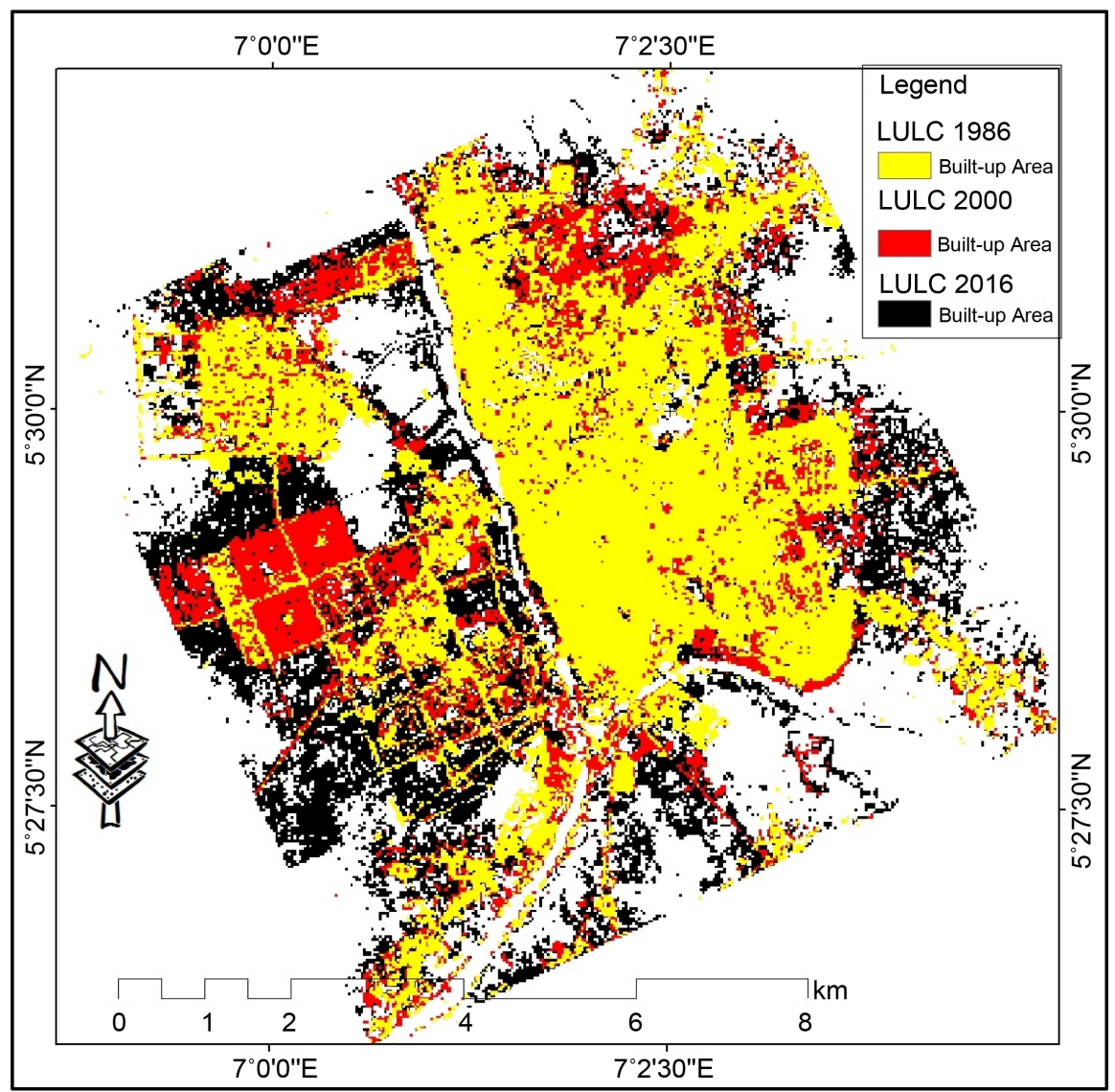

Figure 6. Change detection of built-up cover from 1986, 2000 and 2016. Source: Stanley I. Echebima, Andrew A. Obafemi and Benjamin C. Ndukwu.

2016 occupying more than half of the study area as depicted in Figure 6. Thus, land use transitional model through those decades can be summarized as high and fast forest depletion and an inversely high and fast rate in the built-up cover. These changes in the LCLUC class, as the years progressed from 1986 through 2000 to 2016, is summarized in Table 6 with negative (-ve) or positive (+ve) differences signifying depletion or growth in the LCLUC class.

That farm/vegetation was fluctuating between the years of this study, may signify that there is an earlier need for food as population grows, but after the year 2000 , there is pressure on the land for housing. Another important observation is the increase in water bodies which "ground truth" visit to Otamiri and Nworie rivers revealed massive sand harvesting at the river bed and river banks and also abuse of riparian lands for physical structures. In like manner, the increase in open spaces in 2016 are not necessarily leisure parks, play grounds or open spaces in its real sense, because pre-existing ones have been encroached upon due to pressure on land for physical infrastructure. The increase in open spaces is the deforested areas that have been cleared, preparatory for buildings.

\subsection{Trend in Land Cover Land Use from 1986 to 2016}

The percentage of space occupied by each land cover land use class is shown in 


\section{Table 7.}

The data in Table 7 is then transposed into a graph and linear regression analysescarried out in order to determine the trend (or rate of change per year) in LCLUC class in Owerri and environs. The results are shown in Figure 7(a) and Figure 7(b).

From, the graphs in Figure 7(a) and Figure 7(b), the following results of the study can be deduced:

1) Forests/thick vegetation cover is decreasing at a rate of $0.73 \%$ of the total land mass per year or $59.61 \mathrm{Ha}$ per year.

2) Farmland/sparse vegetation cover is depleting at a rate of $0.05 \%$ of the total land mass per year or 3.75 Ha per year.

3) Built up areas are increasing at a rate of $0.65 \%$ of the total land mass per year or $53.22 \mathrm{Ha}$ used per year.

4) Open spaces are increasing at $0.11 \%$ of land mass per year or $8.58 \mathrm{Ha}$ per year which may not be for leisure parks or play grounds because some traditional open parks have been encroached upon due to pressure on land for physical strictures.

5) Water bodies are increasing at $0.02 \%$ of land mass or $1.56 \mathrm{Ha}$ per year due perhaps to the excavation of sand at the river banks, gully erosion and abuse of riparian land to meet construction needs.

Table 6. Distribution of the changes in the LCLUC class in 2000 and 2016.

\begin{tabular}{|c|c|c|c|c|c|c|c|c|}
\hline \multirow{2}{*}{$N A M E$} & \multirow{2}{*}{$\begin{array}{c}\text { Area } \\
(\mathrm{Ha}), \\
1986\end{array}$} & \multirow{2}{*}{$\begin{array}{l}\text { Area } \\
(\mathrm{Ha}), \\
2000\end{array}$} & \multicolumn{2}{|c|}{$\begin{array}{c}\text { Change } \\
\text { Detection }\end{array}$} & \multirow{2}{*}{$\begin{array}{l}\text { Area } \\
(\mathrm{Ha}), \\
2000\end{array}$} & \multirow{2}{*}{$\begin{array}{l}\text { Area } \\
(\mathrm{Ha}), \\
2016\end{array}$} & \multicolumn{2}{|c|}{$\begin{array}{c}\text { Change } \\
\text { Detection }\end{array}$} \\
\hline & & & $\mathrm{Ha}$ & $\%$ & & & $\mathrm{Ha}$ & $\%$ \\
\hline Built-up Area & 2834.55 & 3111.12 & 276.57 & 3.39 & 3111.12 & 4410.72 & 1299.60 & 15.94 \\
\hline Farm/ Vegetation & 1979.28 & 2273.85 & 294.57 & 3.61 & 2273.85 & 1881.9 & -391.95 & -4.81 \\
\hline Forest & 3049.65 & 2563.38 & -486.27 & -5.96 & 2563.38 & 1276.56 & -1286.82 & -15.78 \\
\hline Open Space & 184.59 & 105.3 & -79.29 & -0.97 & 105.3 & 433.35 & 328.05 & 4.02 \\
\hline Water Body & 104.4 & 98.82 & -5.58 & -0.07 & 98.82 & 149.94 & 51.12 & 0.63 \\
\hline
\end{tabular}

Source: Stanley I. Echebima, Andrew A. Obafemi and Benjamin C. Ndukwu.

Table 7. Trend in land cover and land use changes from 1986 to 2000 and 2016.

\begin{tabular}{|c|c|c|c|c|c|c|}
\hline YEAR & 1986 & & 2000 & & 2016 & \\
\hline LCLU Class & $\begin{array}{c}\text { Area } \\
\text { Taken } \\
(\mathrm{Ha})\end{array}$ & $\begin{array}{l}\% \text { of } \\
\text { Total } \\
\text { Area }\end{array}$ & $\begin{array}{c}\text { Area } \\
\text { Taken } \\
(\mathrm{Ha})\end{array}$ & $\begin{array}{l}\% \text { of } \\
\text { Total } \\
\text { Area }\end{array}$ & $\begin{array}{c}\text { Area Taken } \\
(\mathrm{Ha})\end{array}$ & $\begin{array}{l}\% \text { of } \\
\text { Total } \\
\text { Area }\end{array}$ \\
\hline Built-up Area & 2834.6 & 34.77 & 3111.12 & 38.16 & 4410.72 & 54.10 \\
\hline Farm/Vegetation & 1979.3 & 24.28 & 2273.85 & 27.89 & 1881.9 & 23.08 \\
\hline Forest & 3049.7 & 37.41 & 2563.38 & 31.44 & 1276.56 & 15.66 \\
\hline Open Space & 184.59 & 2.26 & 105.3 & 1.29 & 433.35 & 5.32 \\
\hline Water Body & 104.4 & 1.28 & 98.82 & 1.21 & 149.94 & 1.84 \\
\hline TOTAL & 8152.47 & 100 & 8152.47 & 100 & 8152.47 & 100 \\
\hline
\end{tabular}

Source: Stanley I. Echebima, Andrew A. Obafemi and Benjamin C. Ndukwu. 


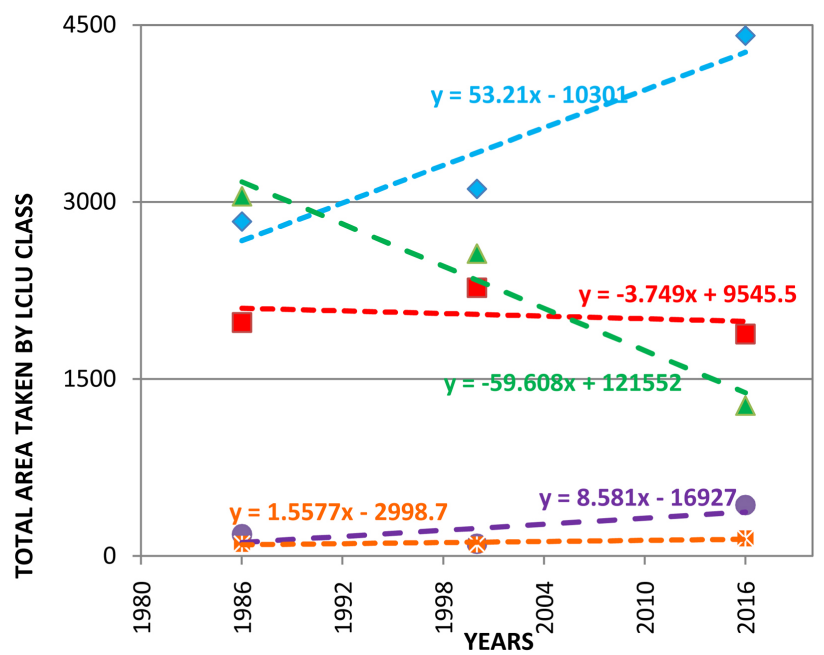

- Built Up area

- Farm/Vegetation

A Forest

- Open Space

* Water Body

$-\infty-$ Built Up Area Trend

- - - Farm/Sparse Vegetation

- Forest/Thick Vegetation

- Open Space

(a)

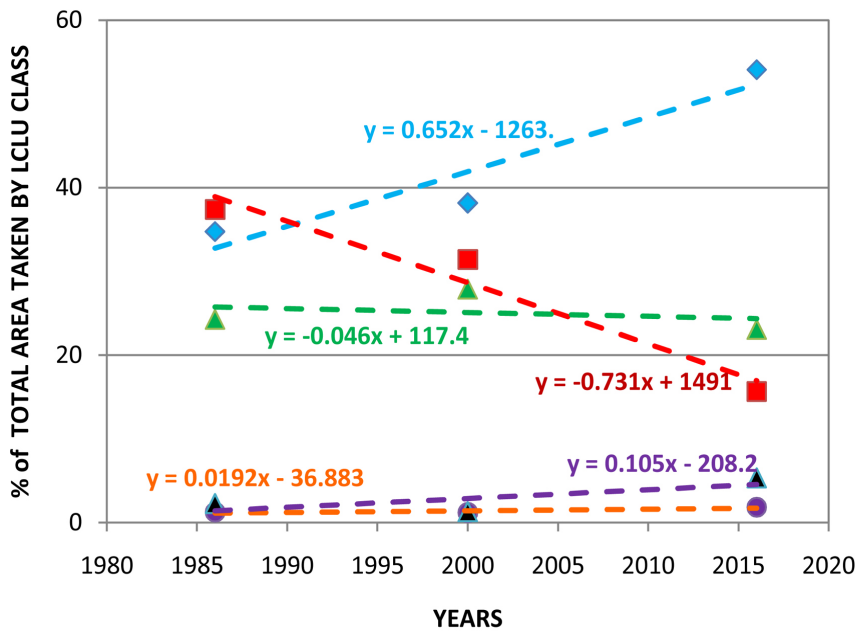

$\checkmark \quad \%$ Built Up Area

- \% Forest

A \% Farmland/ Vegetation

- \% Water Body

\ \% Open Space

- Built Up Area

- Forest

- Farm/Sparse Vegetation

- Water Body

(b)

Figure 7. (a) Trend of land cover and land use class by the total area occupied showing the area in hectares used per year. Source: Stanley I. Echebima, Andrew A. Obafemi and Benjamin C. Ndukwu. (b) Trend of land cover and land use class as a percentage of the total study area indicating the percentage change per year of each land use class. Source: Stanley I. Echebima, Andrew A. Obafemi and Benjamin C. Ndukwu.

6) Sand excavation on the banks of the river and physical structures is depleting the riparian lands, with its attendant consequences.

\section{Conclusions}

Within the period under study from 1986 to 2016, we can conclude as follows that:

1) Adverse Land Cover and Land Use Changes have taken place in Owerri and environs leading to a high rate of loss of combined thick and sparse vegetal cover at $0.78 \%$ of the land cover per year, with the implication of changing the local climate of the area.

2) Urbanization has increased with little or no spatial planning or controls at 
an alarming rate at $0.65 \%$ of the land mass per year, which will likely affect urban life, waste management and the climate of the area.

3) Consequent upon item 2 above, Open spaces and water bodies marginally increased respectively at $0.11 \%$ per year and $0.02 \%$ per year of the total land mass due perhaps to opened-up forest/vegetal cover and sand harvesting at the banks/beds of Otamiri River and Nworie River.

4) The riparian lands surrounding the two rivers (Otamiri and Nworie) have suffered depletion due to encroachment.

5) At the rate of conversion of vegetal cover to built-up infrastructure, if it is not arrested and proper urban re-planning with greening followed, the entire vegetation in the area could be depleted in about 2 decades in 2039.

\section{Recommendations}

Based on the findings of the study, we make the following recommendations:

1) There is a need to urgently limit and control the high rate of deforestation going on in Owerri and environs and embark on tree planting campaigns without delay by all stakeholders.

2) Urbanization and other infrastructural developmental efforts should be approached by the government through proper urban spatial planning and controls, sustainable land and natural resources use.

3) There is need to embark on water shed management of the Otamiri River and Nworie River including proper management/control of sand mining and conservation of the riparian lands in order to avoid erosion, ecological and hydrological disasters.

4) The authorities of the area should create an awareness programme for all stakeholders on the issues at hand and the need to adopt sustainable use of natural resources, sustainable living habits and minimizing impact on the environmental.

5) Future Work:

For the future work on this or similar study we recommend as follows:

a) There is a need to use tools like Markov Chain approach to model the LCLUC transitions of Forests/Vegetal Cover into Built-Up space in the future say in 2040 .

b) Higher quality satellite imagery like IKONOS (which became commercially available in the year 2000) that offers up to $4 \mathrm{~m}$ resolution should be used.

\section{Conflicts of Interest}

The authors declare no conflicts of interest regarding the publication of this paper.

\section{References}

[1] FAO (2000) Corporate Document Repository, Land Cover Classification System. http://www.fao.org/docrep/003/x0596e/x0596e01e.htm 
[2] Byravan, S. (2017) How Land Use Affects Climate Change. https://www.thehindu.com/opinion/op-ed/How-land-use-affects-climate-change/ar ticle17117899.ece

[3] Foley, J.A. and De Fries, R. (2005) Global Consequences of Land Use. Science Journal, 309, 570-574. https://doi.org/10.1126/science.1111772

[4] Austine, N.O., Richard, N.E. and Chibuike, P.C. (2016) Spatio-Temporal Analysis of Land Use Changes in Owerri and Environs.

[5] Okeke, P.N. (2015) An Assessment of Two Decades of Land Use Changes in Owerri. http://www.skyjournals.org/sjssem/Pdf/2015/Nov/Okeke\%20pdf.pdf http://www.skyjournals.org/sjssem/Abstract/2015/Nov/Okeke.htm

[6] Chukwuocha, A.C. and Blessing, N. (2015) Dynamics of Land Use Changes in Otamiri Watershed of Owerri, South East Nigeria.

[7] NPC Nigeria (2009) 2006 Population and Housing Census 2006 Vol. 1.

[8] Eludoyin, O.S., Wokocha, C.C. and Ayolagha, G. (2011) GIS Assessment of Land Use and Land Cover Changes in OBIO/AKPOR L.G.A., Rivers State, Nigeria. Research Journal of Environmental and Earth Sciences, 3, 307-313.

[9] Hamad, R., Balzter, H. and Kolo, K. (2018) Predicting Land Use/Land Cover Changes Using a CA-Markov Model under Two Different Scenarios. Sustainability, 10, 3421. https://www.mdpi.com/2071-1050/10/10/3421/pdf https://doi.org/10.3390/su10103421

[10] Radhakrishnan, K.N. and Mathew, S. (2014) Land Use Change Modelling Using a Markov Model and Remote Sensing. Geomatics, Natural Hazards and Risk, 5, 145-156. https://doi.org/10.1080/19475705.2013.795502

[11] Keshtkar, H. and Voigt, W. (2016) A Spatiotemporal Analysis of Landscape Change Using an Integrated Markov Chain and Cellular Automata Models. Modeling Earth Systems and Environment, 2, 10. https://doi.org/10.1007/s40808-015-0068-4

[12] Saleska, S. (2010) Land Use Change.

[13] IPCC (2014) Climate Change: Synthesis Report Summary for Policy Makers. 5.

[14] Onyenechere, E.C. (2010) Climate Change and Spatial Planning Concerns in Nigeria: Remedial Measures for More Effective Response. Journal of Human Ecology, 32, 137-148. https://doi.org/10.1080/09709274.2010.11906333

[15] Echebima, S., Ndukwu, B. and Obafemi, A. (2019) Climate Study of Owerri and Comparative Analysis of Different Methods of Base Factor Computation. Atmospheric and Climate Sciences, 9, 310-322. https://doi.org/10.4236/acs.2019.93022

[16] Anderson, J.R., Hardy, E.E., Roach, J.T. and Witmer, R.E. (2001) A Land-Use and Land-Cover Classification System for Use with Remote Sensor Data. https://doi.org/10.3133/pp964

[17] Beck, H.E., Zimmermann, N.E., McVicar, T.R., Vergopolan, N., Berg, A. and Wood E.F. (2018) Present and Future Koopen-Geiger Climate Classification Maps at 1-km Resolution. Scientific Data, 5, Article No. 180214. https://doi.org/10.1038/sdata.2018.214

[18] Climate-Data.org (2016) Climate: Owerri. https:/en.climate-data.org/africa/nigeria/imo/owerri-889379/?amp=true

[19] UNEP/FAO (1994) Harmonizing Land Cover and Land Use Classifications.

[20] FAO (2017) Land Cover Classification System. http://www.fao.org/3/x0596e/X0596e01d.htm http://www.fao.org/3/x0596e/x0596e00.htm 
[21] Njoku, J.D., Ukaegbu, K.O., Amangabara, G.T., Iwuji, M.C. and Anyanwu, J.C. (2015) Correlation of Impervious Surfaces and Ambient Temperature Variation in Owerri.

[22] Ukaegbu, K.O.E., Iwuji, M.C., Uche, C.C., Osumgborogwu, I.E. and Amangabara, G.T. (2015) Spatial Assessment of Temperature and Land Cover Change as Climate Change Monitoring Strategies in Owerri, Nigeria. 